\title{
Порівняльна морфологічна характеристика гострої та хронічної рани у хворих на синдром діабетичної стопи
}

\author{
P. O. HERASYMCHUK, A. V. PAVLYSHYN, T. K. HOLOVATA \\ SHEI "Ternopil State Medical University by I. Ya. Horbachevsky"
}

\section{COMPARATIVE MORPHOLOGICAL CHARACTERISTICS OF AN ACUTE AND CHRONIC WOUND IN PATIENTS WITH SYNDROME OF DIABETIC FOOT}

\begin{abstract}
На основі вивчення 127 гістологічних препаратів, виготовлених із біопсійнго матеріалу, взятого інтраопераційно у 23 хворих на синдром діабетичної стопи (СДС), вивчено морфологічні особливості гострої та хронічної рани. Встановлено, що хронічна рана вирізнясться вираженим гальмуванням репаративних процесів. Розлади мікроциркуляції, посднані з запаленням та спотвореною регенерацісю, призводять до формування своєрідного хибного кола, при якому хронізація запалення сприяє незавершеній регенерації та формуванню персистуючої грануляційної тканини.

Based on the study of 127 histological preparations made of biopsy material, taking intraoperative in 23 patients with syndrome of diabetic foot, there were studied the morphological peculiarities of an acute and chronic wounds. It was found out that chronic wound differs with pronounced breaking reparatory processes. Disorders of microcirculation, combined with inflammation and distorted regeneration, lead to the formation of a false range, at which the chronical inflammation contributes to the incomplete regeneration and formation of persistent granulation tissue.
\end{abstract}

Постановка проблеми і аналіз останніх досліджень та публікацій. Патогенез формування ранових дефектів у хворих на синдром діабетичгної стопи (СДС) має складний характер, який зумовлюється наявністю діабетичних мікро- та макроангіопатій, нейропатій. Це викликає розвиток хронічної ішемії тканин та виражених метаболічних порушень, що певною мірою спотворює перебіг фаз ранового процесу як при виникненні гострої рани, так і при формуванні хронічного ранового процесу та трофічних виразок [1-5].

Тривале порушення трофіки тканин у хворих на СДС викликає не лише метаболічні зміни, але і призводить до розвитку грубих морфологічних змін у тканинах, які можуть мати самостійне значення в розвитку та перебігу гнійно-некротичних уражень, що недостатньо висвітлено в науковій літературі. Тому вивчення особливостей морфологічних змін у хворих на СДС із гострими та хронічними рановими дефектами дозволить доповнити патогенетичні ланки формування, перебігу та лікування вищеозначеної патології.

Мета роботи: вивчити особливості морфологічних змін тканин у хворих на синдром діабетич- ної стопи з гострими та хронічними ранами нижніх кінцівок.

Матеріали і методи. Вивчено 127 гістологічних препаратів у порівнянні з клінічною динамікою патологічного процесу. Препарати виготовлені $з$ біопсійного матеріалу, взятого у 23 хворих на СДС, які перебували на стаціонарному лікуванні в клініці загальної хірургії протягом 2011-2012 року. Чоловіків було 14, жінок - 9, віком від 46 до 62 років. Гострі рани діагностовано в 11 пацієнтів, хронічні рани та трофічні виразки - у 12 хворих. Забір морфологічного матеріалу проводили інтраопераційно та під час перев'язок таким чином, щоб на одному рівні дослідити шкіру з підшкірною основою, фасції, сухожилки, м'язи.

При виконанні морфологічних досліджень було використано загальноприйняті гістологічні методики. Вивчення оглядових гістологічних препаратів проводили після забарвлення гематоксиліном та еозином, пірофуксином за Ван Гізон. Для тонкого дослідження еластичних фібрил, які відіграють певну роль у регенеративних процесах, застосовували методики забарвлення за Хартом і Вайгертом. 
Результати досліджень та їх обговорення. Мікроскопічне дослідження гострої рани встановило комплекс динамічних морфологічних змін, які стосувалися усіх шарів шкіри. У ранньому періоді головною ознакою були деструктивно-некротичні зміни та виражені розлади кровообігу. Епідерміс у краях рани зазнавав дистрофічних змін - епітелій вакуолізовувався і злущувався. Подекуди він був частково або повністю відсутній.

У поверхневих та глибоких шарах дерми, підшкірній клітковині та м'язовому шарах переважали зміни, зумовлені реакцією судинного русла. Так, у судинах різного калібру мало місце повнокрів'я дилатованих судин із стазом крові, сладжем еритроцитів та тромбоутворенням. Такі порушення супроводжувалися геморагіями, випаданням фібрину та набряком, найбільше вираженими в маргінальних зонах рани. Водночас спостерігали дистрофічні, некробіотичні та некротичні зміни волокнистих структур дерми (рис. 1).

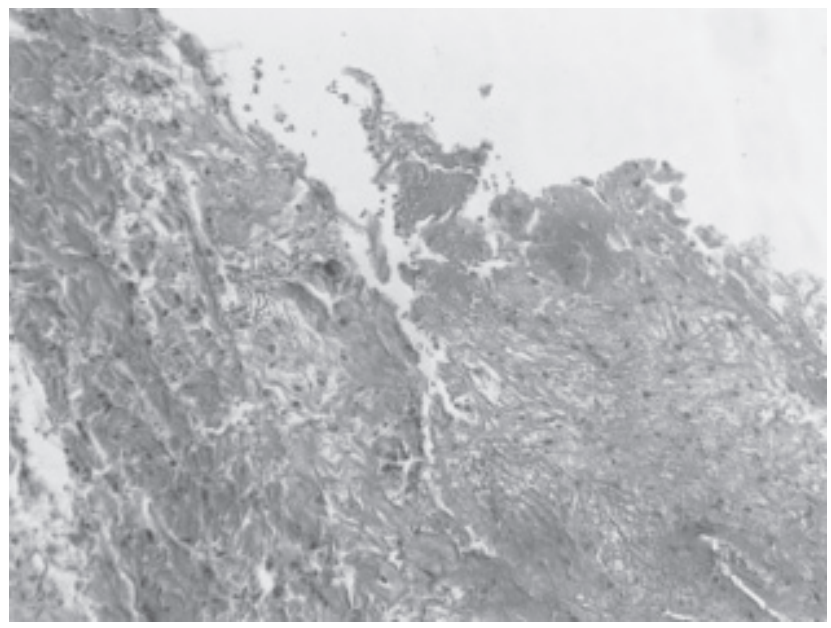

Рис. 1. Ділянка маргінальної зони гострої рани в ранньому періоді. Розрихлення дерми набряком, початкова запальна реакція, дифузні крововиливи серед дрібних фрагментів некротизованої тканини. Гематоксилін та еозин. Об. $10^{\times}$. Ок. $10^{\times}$.

Паралельно з цим формувався запальний інфільтрат, який охоплював усі шари шкіри і поширювався на гіподерму та м'язи, проникаючи у перита ендомізій. У складі інфільтрату переважали полінуклеарні лейкоцити, макрофаги і лімфоцити. Слід зазначити, що альтеративних змін зазнавали переважно епітеліальні структури, колагенові та еластичні волокна. Водночас зберігався відносно високий об'єм судин. На судинні стінки також поширювався запальний процес із розвитком ендо- та панваскуліту.

Суттєві зміни в динаміці гострого ранового процесу починали виявлятися з 5-7-ї доби. Так, змен- шувалася інтенсивність запальної реакції, в складі інфільтрату починали переважати лімфоцити та макрофаги. 3'являлися поодинокі гігантські багатоядерні клітини. Тканинний детрит резорбувався. Натомість спостерігалася виражена фібропластична реакція. Хоча незначна частина судин мікроциркуляторного русла перебувала в дилатованому стані, інша, в глибоких, поверхневих сплетеннях і в краях рани, мала всі ознаки регенерації. У гіподермі та в ділянці фасцій спостерігали проліферацію ендотелію, який формував вертикальні трубчасті структури у напрямку ранової поверхні. Тут же активно проліферували фібробласти. У краях рани також мали місце подібні зміни, проте їх поширення було спрямовано паралельно рановій поверхні. Формувався масив грануляційної тканини з високою щільністю тонкостінних судин та переважною інфільтрацією лімфоцитами (рис. 2).

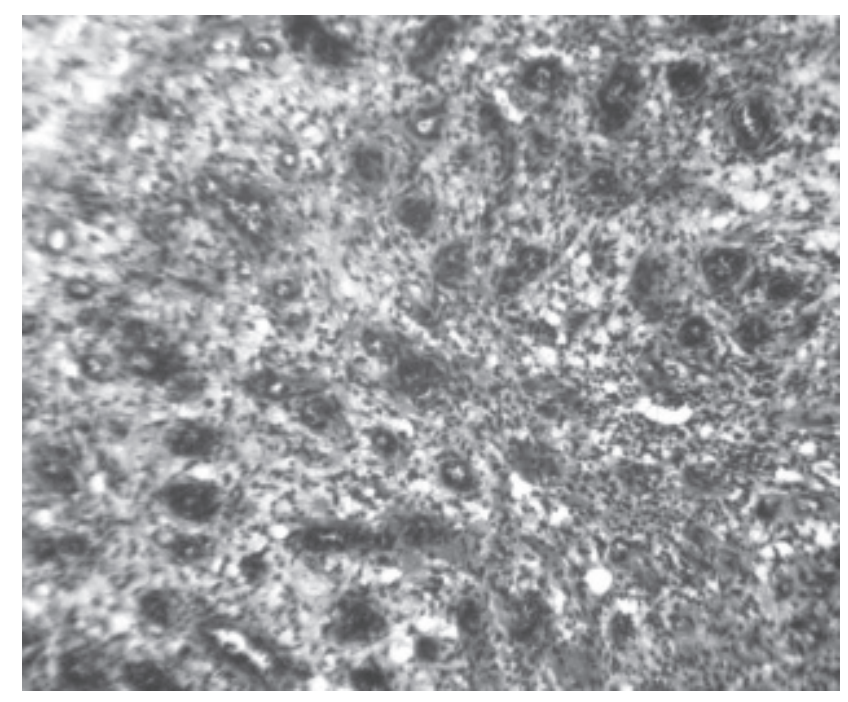

Рис. 2. Фрагмент грануляційної тканини на 14-й день регенераторного процесу гострої рани. Серед численних судин тонкі колагенові волокна та клітинна інфільтрація, в якій переважають лімфоцити та макрофаги. Гематоксилін та еозин. Об. $20^{×}$. Ок. $10^{×}$.

Волокнисті структури в цей період майже не візуалізувалися або були представлені тонкопетлистою сіткою $з$ великою кількістю клітин гістіоцитарного та гематогенного походження. У краях рани відзначали ознаки проліферації базальних шарів епідермісу. До кінця 4-го тижня спостерігали повне дозрівання та ремоделювання сполучної тканини з епітелізацією ранової поверхні.

При гістологічному дослідженні рани з хронічним перебігом відзначали якісно та кількісно інші структурні прояви. Зміни стосувалися перш за все уже попередньо сформованої грануляційної тканини, зокрема судин мікроциркуляторного русла. У капі- 
лярах, венулах і артеріолах мали місце ознаки стазу, аглютинації еритроцитів, набряк та набухання ендотеліоцитів, їх злущування. Часто зустрічалися мікротромби змішаного характеру. Просвіти багатьох судин були значно звужені, стінки потовщені за рахунок плазматичного просякання, фібриноїдного некрозу або склерозу. Відбувалася проліферація ендотеліоцитів та перицитів, інфільтрація судинних стінок численними полінуклерами із формуванням проліферативно-інфільтративних, деструктивних панваскулітів та тромбоваскулітів (рис. 3).

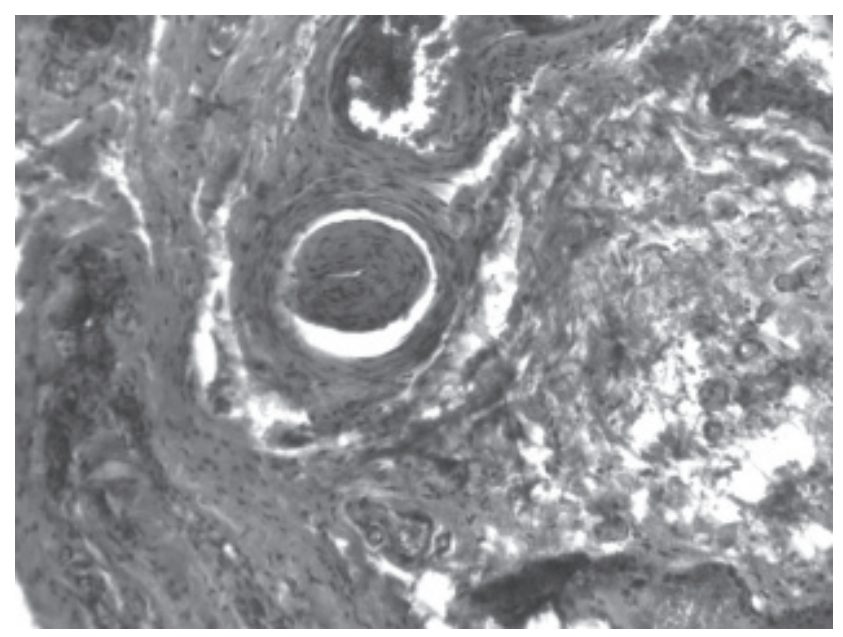

Рис. 3. Фрагмент грануляційної тканини хронічної рани. Повнокрів'я судин із порушенням реологічних властивостей крові - сладж-феномен, потовщення судинних стінок. У просвіті - фібрин із домішком злушених клітин ендотелію. Гематоксилін та еозин. Об. 20×. Ок. $10^{×}$.

Такі пертурбації в судинах викликали множинні некрози грануляційної тканини. В усіх шарах ранового дефекту спостерігали виражену запальну реакцію. Особливо слід відзначити переважаючий вміст в інфільтраті поліморфноядерних лейкоцитів i незначну кількість, на відміну від гострих ран, моноцитів та макрофагів. Також у малій кількості виявлялися лімфоцити, серед яких переважали малі форми. Рідко зустрічалися плазмоцити. Кількість фібробластів знижена, частина клітин представлена незрілими формами. Колагенові фібрили тонкі, в невеликій кількості, з ознаками дезорганізації.

Відмінних від гострого перебігу структурних змін зазнавали й інші компоненти хронічної рани. Так, в епідермісі по краю ранового дефекту відзначали ознаки порушення диференціювання, дистрофічні зміни клітин шипуватого і зернистого шарів. Як правило, мали місце гіперкератоз, паракератоз та акантоз (рис. 4).

Поряд з явищами гіпертрофії виявляли ділянки атрофії шкіри. У дермі збільшувалася кількість колагенових волокон, які мали вигляд грубих гомо-

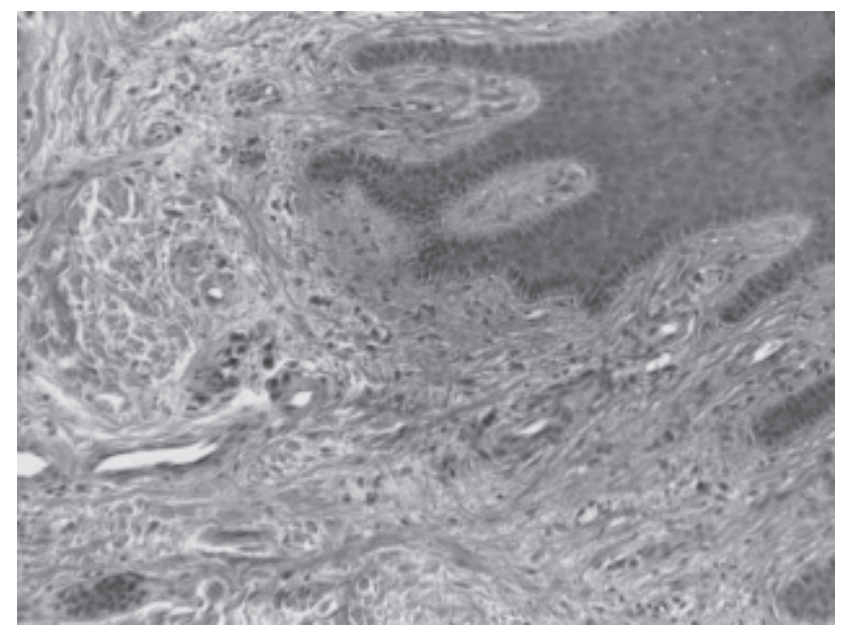

Рис. 4. Фрагмент шкіри з краю ранового дефекту. Гіперплазія епідермісу з акантозом, колагенізація дерми та склероз судин поверхневого сплетення. Гематоксилін та еозин. Об.10×. Ок. $10^{\times}$.

генних пучків, а кількість придатків шкіри різко зменшувалася. Проліферація епітеліальних клітин базальних шарів епідермісу в краях ранового дефекту, порівняно з такою в гостій рані, була слабовираженою. Іноді виявляли некрози епітеліального пласту. В дрібних судинах поверхневого та глибокого сплетень спостерігали склеротичні зміни. Вважають, що такі зміни сприяли поглибленню мікроциркуляторних розладів, посилюючи тим самим гіпоксичні впливи безпосередньо на грануляційну тканину ранової поверхні та зумовлюючи $\dddot{1}$ схильність до дегенеративних змін.

В окремих гістопрепаратах виявляли поперечні зрізи нервових стовбурів із вираженими дегенеративними проявами - стоншувався периневрій, спостерігали розпад та лізис нервових волокон.

Висновки. 1. Хронічна рана відрізняється гальмуванням репаративних процесів, що проявляється різким розладом у системі мікроциркуляції, пролонгованою запальною та ослабленою макрофагальною реакціями, слабовираженою проліферацією та диференціюванням фібробластів, пригніченням колагеноутворення.

2. Розлади мікроциркуляції, поєднані з порушеннями взаємозв'язку між самим пошкодженням, запаленням та спотвореною регенерацією, призводять до формування своєрідного хибного кола, за якого хронізація запалення сприяє незавершеній регенерації та формуванню персистуючої грануляційної тканини.

Перспективи подальших досліджень. Подальше детальне вивчення морфологічних змін тканин при гострій і хронічній рані у хворих на СДС 
дозволить оптимізувати характер та об'єм хірургічних втручань, а також скорегувати схеми комп-

\section{СПИСОК ЛІТЕРАТУРИ}

1. Абаев Ю. К. Раны и раневая инфекция. Справочник хирурга / Ю. К. Абаев. - Ростов на Дону : Феникс, 2006. - 427 с.

2. Синдром диабетической стопы в клинической практике/ В. Н. Оболенский, Т. В. Семенова, П. Ш. Леваль, А. А. Плотников // Русский мед. журнал. - 2010. - № 2. - С. 45-58.

3. Синдром диабетической стопы / [И. В. Гурьева, И. В. Кузина, А. В. Воронин и др.]. - М. : Медицина, 2000. - 40 с. лексного патогенетичного консервативного лікування означених пацієнтів.

4. Удовиченко О. В. Диабетическая стопа / О. В. Удовиченко, Н. М. Грекова. - М. : Практическая медицина, 2010. $272 \mathrm{c}$.

5. Храмилин В. Н. Современные аспекты местного лечения хронических ран нижних конечностей у больных сахарным диабетом / В. Н. Храмилин // Сахарный диабет. - 2005. - № 4. C. $1-8$. 